\title{
Fərdi məlumatların tənzimlənməsinə siyasi-hüquqi nəzər: beynəlxalq və Azərbaycan qanunvericiliyi
}

\author{
Rəna Mirzəzadə \\ AMEA Fəlsəfə İnstitutu, Bak1, Azərbaycan
}

Fərdi məlumatlar anlayışı özündə fərd haqqında kimliyini birbaşa və ya dolayısı ilə müəyyənləşdirməyə imkan verən istənilən məlumatdan gedir. Bəs fərdi məlumatların subyekti nədir? $\mathrm{Bu}$, barəsində fərdi məlumatlar toplanılan, işlənilən və mühafizə edilən, kimliyi müəyyənləşdirilmiş və ya müəyyənləşdirilən subyektdir.

Akademik R.Mehdiyevin yazdığı kimi: "universal səviyyədə informasiya məkanında fərdin təhlükəsizliyinin və azadlığının mənafeləri arasında tarazlığa əsaslanan informasiya təhlükəsizliyinin vahid standartlarının və meyarlarının müəyyən edilməsi zəruridir" [13].

$\mathrm{Bu}$ aspektdən fərdi məlumatların toplanması isə hər subyekt haqqında fərdi məlumatların sənədləşdirilmiş qaydada, qanuna uyğun olaraq əldə edilməsindən ibarətdir. Bəs fərdi məlumatlar necə verilir? Belə ki, fərdi məlumatlar qanunvericiliklə müəyyən edilmiş qaydada sorğu əsasında, maddi daşıyıcılarla və ya informasiya texnologiyaları vasitəsilə istifadəçilərə təqdim edilir. Akademik Rasim Oliquliyev göstərir ki: “dövlət hakimiyyətinin dayanıqlılığ1, təhlükəsizliyi və effektiv fəaliyyətinin təmin edilməsi mürəkkəb komponentli və operativ məlumat bazalarının, o cümlədən fərdlər haqqında məlumatların toplanmasını, analizini və sistemləşdirilməsini zəruri edir" [3; 117]. Məhz bu aspektdən də mövzu aktualdır. Bəs onun həlli yolları necədir. Nəzərə yetirək ki, fərdi məlumatların məxfiliyi qorunmalıdır. Fərdi məlumatların məxfiliyi inkişaf etmiş ölkələrdə qanunvericiliklə nizamlanır. İlk dəfə 1981-ci il 28 yanvarda Strasburqda Avropa Şurası tərəfindən "Fərdi məlumatların avtomatlaşdırılmış qaydada işlənməsi ilə əlaqədar şəxslərin qorunması haqqında" Konvensiya qəbul edildi $\mathrm{ki}$, bu da fərdi məlumatların mühafizəsi və məxfiliyin qorunması üzrə əsas sənəddir. Konvensiyanı AŞ üzvü 43 ölkə ratifikasiya etdi və digər ölkələr tərəfindən imzalanmaq üçün açıq qaldı. Konvensiya 1985-ci il 1 oktyabrdan qüvvəyə minmişdir. Konvensiya Avropa Şurasına üzv olan bütün ölkələr, eləcə də AŞ-nın üzvü olmayan - Uruqvay (2013-cü ildə ilk Avropadan kənar ölkə olaraq), Mavriki (2016), Seneqal (2016), Tunis (2017), KaboVerde (2018), Meksika (2018), 2019-cu ildə Argentina, Meksika tərəfindən qəbul olunmuşdur. Konvensiyanı ratifikasiya etmiş ölkələr üçün məcburi olsa da, Avropa İnsan Hüquqları Məhkəməsinə müraciət üçün əsas deyil [5]. AŞ-nin keçmiş baş katibi Torbyorn Yaqland qeyd etdiyi kimi: "Konvensiya ölkələr arasında fərdi məlumatların mühafizəsi sahəsində möhkəm qaydalar və qanunlar bazası olmaqla yanaşı, həmçinin bu sahədə qlobal mərhələdə əməkdaşlıq üçün xüsusi format yaradır" [10].

1985-ci ildən keçən dövr ərzində Konvensiya yenilənmiş, son olaraq da “süni intellekt”lə bağlı müddəalar əlavə olunmuşdur. Süni intellekt sistemlərinin geniş istifadəsi, xüsusilə bu sahədə məlumatların istifadəsi ilə bağlı təhlükə yaratmışdır və bu təhlükə yalnız dövlət qurumlarına məxsus resurslarla bağlı deyil, həmçinin müxtəlif onlayn servislərlə bağlıdır. Beləliklə "Fərdi məlumatların avtomatlaşdırılmış qaydada işlənməsi ilə əlaqədar şəxslərin qorunması haqqında" Konvensiyanın Məsləhətçi Komissiyası 25 yanvar 2019-cu ildə "Süni intellekt və məlumatların qorunması haqqında qaydalar" qəbul edir [6]. Bu, 28 Yanvar - Məlumatların mühafizəsi günündə nəşr edilir. 28 yanvar tarixinin "Məlumatların mühafizəsi günü” kimi qeyd olunması da 1981-ci ildə bu Konvensiyanın ilk dəfə imzalandığı günlə bağlıdır. Konvensiyada şəxsin irqi və siyasi mənsubluğu, tibbi məlumatları, dini etiqad1, cinsi və məhkumluqla bağl1 məlumatları "həssas məlumatlar" kimi qeyd olunur. Nəzərə alsaq ki, bu cür məlumatlar müxtəlif özəl sektora mənsub şəbəkələrdə də mövcuddur və müasir dövrdə İKT-nin geniş istifadəsi də yeni təhlükəsizlik təhdidləri ortaya çıxarır. AŞ Nazirlər Komitəsinin qəbul olunan düzəliş protokolları çatışmazlıqları aradan qaldırmaq imkanı yaradır [11].

Tədqiqatçı Nina Qumzey yazır ki: "Strasburq Konvensiyasının qəbul olunmasının daha bir mühüm cəhəti bu sahədə presedent yaratmaqla yanaşı, son düzəlişlər nəticəsində dövlətlərarası transsərhəd məlumat axınlarına da müəyyən məhdudiyyətlər gətirməsidir. Baxmayaraq ki, bir çox ölkələrin şəxsi məlumatların mühafizəsi sahəsindəki qanunvericiliyi birbirinə yaxındır, lakin milli qanunvericiliyin bu sahədə praktiki olaraq tətbiqi çox zaman ya mümkün olmur, ya da olunsa belə ekvivalent mühafizəni təmin edə bilmir" [9; 13]. Nümunə olaraq, bir ölkə vətəndaşının başqa bir ölkədə olan üçüncü tərəfə məxsus beynəlxalq bir bankda hesabının olması və ya onun başqa ölkələrə səfəri zamanı məlumatlarının toplanılması, saxlanılması problemini göstərmək olar. Beləliklə, fərdi məlumatların ikinci və üçüncü tərəf ölkələr tərəfindən əldə olunmas1 və qorunması problemi yaranır ki, bu zaman hans1 ölkənin qanunlarının tətbiq olunacağını müəyyən etmək asan olmur. Strasburq Konvensiyası isə universaldır və yalnız dövlətlərlə bağlı deyil, həmçinin, özəl sektor, məhkəmə və hüquq-mühafizə orqanları tərəfindən həyata keçirilən bütün 


\section{“Informasiya tohlükosizliyinin aktual multidissiplinar elmi-praktiki problemlori” V respublika konfransı, 29 noyabr 2019-cu il}

məlumat emalı proseslərinə şamil olunur. Məhz bu isə əldə olunan yenilikdir.

Bəs praktiki əhəmiyyəti nədir? Qloria Qonzaloez Fluaster "Fundamental hüquq kimi fərdi məlumatların mühafizəsinin Avropa İttifaqında yaranması" adlı kitabında qeyd etdiyi kimi: "Avropa İttifaqında belə bir qanunun qəbul olunmasına 2 əsas zərurət var idi. Bunlardan birincisi, Aİ leqal sistemi içərisində belə hüququn təbii olaraq ortaya çıxması və buna olan maraq, ikincisi isə o zamanki hüquqi ədəbiyyatda bu problemə çox məhdud çərçivədə toxunulması, həmçinin məhkəmə-hüquq sistemində problemin interpretasiyası və tətbiqi ilə bağlı olan problemlər idi" [7;3-4].

$\mathrm{Bu}$ sahədə müxtəlif ölkələrin qanunvericiliklərində fərqli yanaşmalar mövcuddur və əslində, Konvensiya bu sahədə qəbul olunmuş əsas beynəlxalq akt sayıla bilər. Misal üçün, ABŞ-a istinad etsək, burada bu sahə ilə bağlı qəbul edilmiş xüsusi bir qanun yoxdur. Codi Vestbi "Məxfilik ilə bağlı beynəlxalq məlumat kitabçası" adlı kitabında göstərdiyi kimi: “ABŞ-da dövlət orqanları 1974-cu il "Məxfilik Aktı"na istinad etsə də, özəl sektor Avropa İttifaqında olduğu kimi və ya Kanada qəbul olunmuş "Fərdi Məlumatların Mühafizəsi və Elektron Sənədlər Aktı"1 nümunəsinə uyğun bir qanunvericilik aktlarına tabe deyil. ABŞ-da bu sahədə tənzimləmə qanunlar, administrativ aktlar, məhkəmə qərarları və ştatlara məxsus qanunlarla aparılır, bu isə fərdi məlumatların qorunması ilə bağlı vahid və möhkəm bir baza təmin edə bilmir [8;11].

Bəs Azərbaycanda vəziyyət necədir? Azərbaycanda da fərdi məlumatlarla əlaqədar mükəmməl qanunvericilik bazası vardır. Belə ki, Azərbaycan Respublikası Konstitusiyasının 47ci maddəsi "Fikir və söz azadlığı" adlanır və onun I bəndində yazılıb: "Hər kəsin fikir və söz azadlığı vardır" [1, 17]. Həmçinin Konstitusiyanın 50-ci maddəsi də "Məlumat azadlığı" adlanır. Azərbaycan Respublikası da Strasburq Konvensiyasına qoşulmuş və Konvensiya 30 sentyabr 2009-cu il tarixində Milli Məclisdə təsdiq edilmiş, 2010-cu il 1 sentyabr tarixindən isə qüvvəyə minmişdir. Burada əsas məqsəd: 1) insanları bu məsələlər ilə bağlı maarifləndirmək; 2) - onlar haqqında məlumatların hansı məqsədlərlə toplanıldığını və işlənildiyini anlamaq imkanı yaratmaq; 3) toplanılan fərdi məlumatların subyektlərinə onların hüquqlarını başa salmaqdan ibarotdir.

Bu mənada, fərdi məlumatların toplanması, işlənilməsi və mühafizəsinin əsaslar1, prinsipləri, bu sahədə dövlət tənzimləməsinin qayda və tələbləri, fərdi məlumatların informasiya ehtiyatlarında formalaşdırılması, informasiya sistemlərinin yaradılması, informasiyanın verilməsi və ötürülməsi qaydalarını əsaslandırır. Bu prosesdə iştirak edən şəxslərin hüquqları, vəzifələri və məsuliyyətini müəyyən etmək, insan və vətəndaş hüquqları və azadlıqları, şəxsi və ailə sirrini saxlamaq hüququnu müdafiə etmək məqsədi ilə bu qanun ölkəmizdə də qəbul edilmişdi. Qanun fərdi məlumatların toplanılması, işlənilməsi və mühafizəsi ilə bağlı münasibətləri, milli informasiya məkanının fərdi məlumatlar bölümünün formalaşdırılması, habelə fərdi məlumatların transsərhəd ötürülməsi ilə əlaqədar münasibətlərin tənzimlənməsi, o cümlədən bu sahədə fəaliyyət göstərən dövlət və yerli özünüidarə orqanlarının, hüquqi və fiziki şəxslərin hüquq və vəzifələrini müəyyən edir.

Prezident İlham Oliyev tərəfindən "Fərdi məlumatlar haqqinda" Qanunun tətbiq edilməsi barədə 2010-cu il iyunun 4-də imzalanmış Fərmanda qanunun icrasının təmin edilməsi məqsədi ilə xüsusi tapşırıqlar verilmişdir [2]. Fərmana müvafiq olaraq aidiyyatı dövlət orqanları tərəfindən "Fərdi məlumatların informasiya sistemlərinin dövlət qeydiyyatına alınması və dövlət qeydiyyatının ləğv edilməsi Qaydaları", "Fərdi məlumatların mühafizəsinə dair tələblər", "Fərdi məlumatların informasiya sistemlərinin dövlət qeydiyyatı ləğv edildikdə həmin informasiya sistemlərində olan məlumatların məhv edilməsi Qaydası" və "Dövlət qeydiyyatına alınması tələb olunmayan informasiya sistemləri" sənədləri hazırlanmış və Nazirlər Kabinetinin müvafiq qərarları ilə təsdiq edilmișdir. Prezident İlham Oliyevin fərmanı ilə "Fərdi məlumatların informasiya sistemlərinin dövlət reyestrinin aparılması Qaydaları" da təsdiq edilmişdir [2]. Azərbaycanda qanunla fərdi məlumatların informasiya sistemini dövlət qeydiyyatından keçirmədən toplanılmasına və işlənilməsinə yol verilmir. Bununla yanaşı, qanunda xüsusi istisna hallar da nəzərdə tutulmuşdur. Ümumilikdə, fərdi məlumatların informasiya sistemləri yaradılarkən qanunvericiliklə müəyyən edilmiş qaydada fərdi məlumatların mühafizəsinə dair tələblərə əməl edilməlidir.

Bəs fərdi məlumatlardan necə istifadə etmək olar? Akademik Rasim Oliquliyev yazır ki: "Fordi məlumatlardan istifadə ilə bağlı hüquqi məhdudiyyətlərə baxmayaraq, onlardan qeyri-qanuni biznes və kriminal məqsədlərlə istifadəyə olan tələbat bu sahənin "qara bazarı"nın formalaşmasına rəvac verir. Beləliklə, fərdi məlumatlar həm də kriminalistikanın probleminə çevrilir" [3;117]. Qanuna müvafiq olaraq fərdi məlumatların informasiya ehtiyatlarının formalaşdırılması və informasiya sistemlərinin yaradılması, onlara xidmətlərin göstərilməsi sahəsində fəaliyyət Azərbaycanın qanunvericiliyinə uyğun olaraq xüsusi razılıq (lisenziya) əsasında həyata keçirilməlidir. Bu məqsədlə, qanunun icrasının təmin edilməsi barədə Prezident İlham Oliyev 2010-cu il dekabrın 13-də "Xüsusi razılıq (lisenziya) tələb olunan fəaliyyət növlərinin siyahısı və həmin fəaliyyət növlərinə xüsusi razılıq (lisenziya) verilməsinə görə ödənilən dövlət rüsumunun məbləğləri"qanununa əlavələr edilməsi və müvafiq olaraq bu sahədə lisenziyanın verilməsi üzrə fəaliyyət RİTN-ə tapşırılması haqda fərman vermişdir [4].

Fərdi məlumatlarda subyektin hüquqlarının mühafizəsində gəldikdə, bu sahədə də qanunvericilikdə əsaslı nizamlayıcı mexanizm qurulmuş, hər bir şəxsə informasiya sistemində özü barəsində məlumatların mövcudluğu və həmin məlumatların əldə edilməsi mənbələri haqqinda məlumat almaq, məlumatların toplanılmasına və işlənilməsinə qadağan qoyulmasını tələb etmək və digər hüquqlar verir. Hər bir vətəndaş fərdi məlumatların qanunsuz toplanılması və işlənilməsi, mühafizəsinin təmin edilməməsi, habelə qanunun tələblərinə əməl olunmaması nəticəsində onun hüquqlarının pozulduğu hallarda qanunvericiliklə müəyyən edilmiş qaydada müvafiq icra hakimiyyəti orqanına və ya məhkəməyə şikayət edə bilər. Fikrimizi Akademik Ramiz Mehdiyevin sözləri ilə 


\section{“Informasiya tohlükosizliyinin aktual multidissiplinar elmi-praktiki problemlori” V respublika konfransı, 29 noyabr 2019-cu il}

yekunlaşdıraq: "İnternet təkcə məlumat yığını olmayıb, bəşəriyyətin virtual portretini, yeni fəlsəfəni formalaşdırır. Sosial şəbəkələr ünsiyyəti asanlaşdırmaqla, qarşılıqlı münasibətlərdə yeni platforma yaradır" [12].

\section{İSTINADLAR}

[1] Azərbaycan Respublikasının Konstitusiyası, B, 2016. "Qanun” nəşr, səh.117

[2] AzərTac 20104 iyun.

[3] Oliquliyev R.M., Mahmudov R.S. Milli mentalitet konteksində fərdi məlumatlarin həssasliği və onlarin təhlükəsizliyinin təmin olunmasi məsələləri. İnformasiya cəmiyyəti problemləri jur, 2009, №2, s.117-128.

[4] AzorTac 2010. 13 dekabr

[5] Details of Treaty No.108. https://www.coe.int/en/web/conventions/fulllist/-/conventions/treaty/108

[6] Consultative committee of the convention for the protection of individuals with regard to automatic processing of personal data (conventn 108), guidelines on artificial intelligence and data protection. T-PD(2019)01. Strasbourg, 25 January 2019.

[7] Gloria González Fuster. The Emergence of Personal Data Protection as a Fundamental Right of the EU. Springer International Publishing Switzerland 2014. 273 pages.

[8] International Guide to Privacy By Jody R. Westby, American Bar Association. Section of Science \& Technology Law. (01.12.2005). 247 pages

[9] Nina Gumzej. The council of europe and the right to personal data protection: embracing postmodernity. Conference of the International Journal of Arts \& Sciences, ISSN: 1943-6114 : 6(2): 13-33 pages (2013)
[10] Opening for signature of the Protocol amending the Convention 108 https://uodo.gov.pl/en/539/999

[11] The protection of individuals with regard to automatic processing of personal data in the context of profiling. Recommendation $\mathrm{CM} / \operatorname{Rec}(2010) 13$ and explanatory memorandum. Council of Europe Publishing, F-67075 Strasbourg Cedex

[12] Bax:vaxt.az/?name=xeber@xeber_id=1459

[13] Azertaq.az/xeber/akademik_Ramiz Mehdiyev. Beynəlxalq. informasiyatəhlükəsi.

\section{POLITICAL AND LEGAL CONSIDERATION OF DATA PROTECTION REGULATION: INTERNATIONAL AND NATIONAL LEGISLATION}

\author{
Rena Mirzazadeh
}

ANAS Institute of Philosophy, Baku, Azerbaijan

Abstract - In this article the conception of personal data, its collection and sharing process have been taken into the consideration. First of all, actuality of the topic and how it is represented on international law described thoroughly. Strasbourg Convention, its ratification in European countries, as well as regulation of the issue in those countries are illustrated. Later, Decree of the President Ilham Aliyev considering personal data protection have been interpreted. Analysis also uses global and local authors' thoughts on the matter, such as academician Ramiz Mehdiyev, academician Rasim Aliquliyev. 